\title{
DISCONTENTED MIRACLE
}

Growth, Conflict, and

Institutional Adaptations in China 
This page intentionally left blank 


\title{
Series on Contemporary China - Vol. 10 DISCONTENTED MIRACLE \\ Growth, Conflict, and Institutional Adaptations in China
}

\author{
Edited by \\ Dali L Yang \\ University of Chicago, USA
}




\section{Published by}

World Scientific Publishing Co. Pte. Ltd.

5 Toh Tuck Link, Singapore 596224

USA office: 27 Warren Street, Suite 401-402, Hackensack, NJ 07601

UK office: 57 Shelton Street, Covent Garden, London WC2H 9HE

\section{Library of Congress Cataloging-in-Publication Data}

Discontented miracle : growth, conflict, and institutional adaptations in China / edited by

Dali L. Yang.

p. cm. -- (Series on contemporary China ; v. 10)

Includes bibliographical references and index.

ISBN 978-981-270-354-5 (alk. paper) -- ISBN 981-270-354-3 (alk. paper)

1. China--Economic conditions--2000. 2. China--Social conditions--2000. 3. China--Politics and government--2002.

HC427.95.D59 2007

330.951--dc22 2006048098

\section{British Library Cataloguing-in-Publication Data}

A catalogue record for this book is available from the British Library.

Copyright (C) 2007 by World Scientific Publishing Co. Pte. Ltd.

All rights reserved. This book, or parts thereof, may not be reproduced in any form or by any means, electronic or mechanical, including photocopying, recording or any information storage and retrieval system now known or to be invented, without written permission from the Publisher.

For photocopying of material in this volume, please pay a copying fee through the Copyright Clearance Center, Inc., 222 Rosewood Drive, Danvers, MA 01923, USA. In this case permission to photocopy is not required from the publisher.

Typeset by Stallion Press

Email: enquiries@stallionpress.com

Printed in Singapore. 


\section{Preface and Acknowledgments}

China has enjoyed stellar economic growth for more than a quarter of a century. That growth, following the era of Maoist misrule, has been known as the China Miracle. ${ }^{1}$ Yet the rapid growth amid market-oriented reforms has not been an unalloyed blessing. It has been accompanied by soaring income inequality and rising social tensions. $^{2}$ It has also over-taxed China's resource base and contributed to a crisis of the environment. ${ }^{3}$ Meanwhile, despite the introduction of elections in villages and some urban neighborhoods, the improvement in political participation has lagged behind the substantial improvement in standard of living and other social indicators. Instead, China's leaders have, in the aftermath of the Tiananmen crackdown, steadfastly held back the opening up of the political system.

In this volume, contributors from the disciplines of economics, political science, and sociology consider the theme "Tensions,

\footnotetext{
${ }^{1}$ Justin Yifu Lin, Fang Cai, Zhou Li, The China Miracle: Development Strategy and Economic Reform (Hong Kong: The Chinese University Press, 2003); Alvin Y. So, China's Developmental Miracle: Origins, Transformations, and Challenges (Armonk, NY: M.E. Sharpe, 2003).

${ }^{2}$ For a survey of the literature, see Dali L. Yang, "Economic Transformation and Its Political Discontents in China: Authoritarianism, Unequal Growth, and the Dilemmas of Political Development," Annual Review of Political Science, no. 9 (2006): 150-158.

3 Elizabeth C. Economy, The River Runs Black: The Environmental Challenge to China's Future (Ithaca, NY: Cornell University Press, 2004); Vaclav Smil, China's Environmental Crisis: An Inquiry into the Limits of National Development (Armonk, NY: M.E. Sharpe, 1993).
} 


\section{vi Preface and Acknowledgments}

Conflicts, and Institutions in China." The chapters examine how existing institutions, broadly defined, might have exacerbated tensions in China's evolving economy, society, and polity as well as how institutional developments have been introduced to deal with existing or emerging conflicts and tensions.

We begin with two classic topics, the regulation of the media and the evolving role of the bukou or household registration system. In "Cornering the Market (Chap. 1)," Ashley Esarey sheds interesting light on the dilemmas facing China's censors and publishers in the age of the market and the Internet. While the Propaganda czars continue to rein in the media sector politically, they have nonetheless introduced market incentives to encourage the increasingly diverse media outlets to be both politically acceptable and commercially relevant. In response to these competing demands, the Chinese media industry tends to exhibit symptoms of a sort of schizophrenia. On a broad range of contents the media has become increasingly competitive and open. But, when push comes to shove, the Party-state continues to wield enormous clout over the media industry. Meanwhile, Fei-ling Wang (Chap. 2) zeroes in on the complicated functions of the bukou or household registration system. Though its importance has declined in the reform era, the bukou continues to be a key social and political institution in China. According to Wang, while the bukou system has helped the ruling elite gain socio-political control, it has also generated substantial tensions and is ripe for further reforms.

Chapters 3-5 examine three issue areas that have gained growing prominence in recent years as China's economic boom has engendered more property rights disputes and increased concerns about the environment and consumer safety. In "Resources and Strategies (Chap. 3)," Tianfu Wang and Bobai Li dissect the tensions and conflicts between real estate developers and property buyers that have emerged with the commercialization of residential housing. For Wang and $\mathrm{Li}$, these tensions and conflicts are both a reflection of China's changing social structure and a contributor to the formation of a new social structure. In "Multifaceted State and Fragmented Society (Chap. 4)," Yanfei Sun and Dingxin Zhao examine three 
environmental campaigns to illuminate the complexities of China's environmental movement. On the basis of detailed case studies, Sun and Zhao discuss the conditions under which such campaigns are more likely to succeed. In Chap. 5, Waikeung Tam and Dali Yang draw attention to a scandal involving the sale of fake and substandard milk powder and elucidate the challenges in China's regulatory development. The chapter highlights some of the deficiencies of the food safety regulatory regime and addresses some salient issues concerning the regulatory state building, including the regulatory chasm between urban and rural areas, the appropriate role of the state in socioeconomic regulation, the uncertainties created by government reforms, and the conflict between food safety and employment.

As income inequality has risen, the treatment of the disadvantaged has been high on the policy agenda. Although China in the reform era has sharply reduced the number of people in poverty, it has become more difficult to make further progress in poverty reduction in recent years. In their assessment of China's anti-poverty strategy and policies, Ran Tao and Mingxing Liu (Chap. 6) point to the various disincentives and weaknesses in the current system of spatially defined anti-poverty programs. Their analysis of poverty reduction policies not only points to the need for the adjustment of anti-poverty policies but also raises interesting questions about decentralization and governance in China. Meanwhile, in "Grain for Green or Grain for Gain (Chap. 7)," Jintao Xu and Ran Tao draw on survey data to dissect the acclaimed Grain for Green Program, which the Chinese government introduced at the end of the 1990s to encourage farmers to convert farmland into forests and grassland. While the program has been credited for its beneficial ecological impact, Xu and Tao provide a skeptical view of the Program's political origins. Their discussion of the Program's limitations for environmental protection and for boosting farmers' income is sobering.

Partly to respond to the problems of governance in the localities, the Chinese authorities have introduced elections into the villages. In the final chapter, Su and Yang argue that the promotion of competitive elections at the village level should be complemented by simultaneous improvements in a number of other non-electoral 


\section{viii Preface and Acknowledgments}

areas to enhance the accountability of public officials. The Chinese leadership has paid some attention to these aspects in recent years through the introduction of diverse initiatives, including tax-for-fee reform, new accounting practices, village affairs disclosure, and institutionalized participation in democratic decision making. The interaction between local initiatives and central interventions will shape the future of village democracy and local governance in China.

Several individuals have played indispensable roles in the making of this volume. Mel Gurtov got the project started when he asked me to put together a special issue of Asian Perspective. I wish to thank him for his expert editing of several chapters that appeared in that issue and for his encouragement and good humor. I would like to gratefully acknowledge the permission of Asian Perspective to use materials previously published in vol. 29, no. 4 (chapters $1-3,5,8)$.

Cheong Chean Chian of World Scientific Publishing has been a wonderfully supportive editor. Chris Chhim and Joyce Juanjie Shen served as my able assistants during the editorial process and deserve special thanks. Ran Tao, co-author of Chapters 6-7, wishes to thank the National Science Foundation of China (Project 70303011) and the NSFC Matching Fund of the Institute of Geographical Sciences and Natural Resource Research, the Chinese Academy of Sciences for financial support. 


\section{Contents}

Preface and Acknowledgments $\quad$ v

1. Cornering the Market: State Strategies for 1 Controlling China's Commercial Media Ashley Esarey

2. Brewing Tensions while Maintaining Stabilities: The Dual Role of the Hukou System in Contemporary China Fei-Ling Wang

3. Resources and Strategies: Conflicts and Their 89 Consequences in the Chinese Real Estate Market Tianfu Wang and Bobai Li

4. Multifaceted State and Fragmented Society: Dynamics of Environmental Movement in China Yanfei Sun and Dingxin Zhao

5. Food Safety and the Development of Regulatory Institutions in China Waikeung Tam and Dali L. Yang

6. Poverty Reduction, Decentralization, and Local Governance in China Ran Tao and Mingxing Liu 
x Contents

7. Grain for Green or Grain for Gain: An Empirical Evaluation of the Sloping Land Conversion

Program in China

Jintao Xu and Ran Tao

8. Elections, Governance, and Accountability 267 in Rural China

Fubing Su and Dali L. Yang

Index

About the Contributors

309

About the Editor 